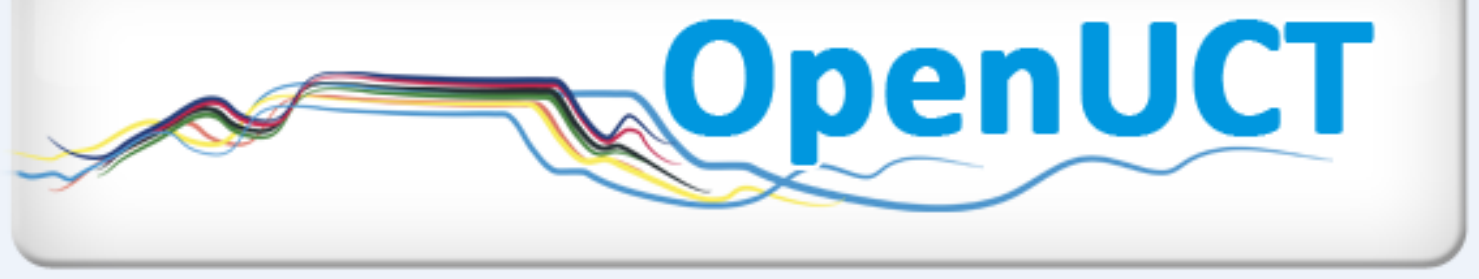

This is the post-print of Paxton, M. 2012. Student voice as a methodological issue in academic literacies research. Higher Education Research \& Development. 31(3): 381-391. DOI:

10.1080/07294360.2011.634382.

It is made available according to the terms of agreement between the author and the journal, and in accordance with UCT's open access policy available:

http://www.openuct.uct.ac.za/sites/default/files/UCTOpenAccessPolicy.pdf, for the purposes of research, teaching and private study. 


\title{
Student voice as a methodological issue in academic literacies research
}

Moragh Paxton*

\author{
Centre for Higher Education Development, University of Cape Town, Cape Town, \\ South Africa
}

\begin{abstract}
Academic literacies research has been identified as an emerging but significant field in higher education. This article extends the discussions around methodology in academic literacies research by drawing on the current text and context debates in sociolinguistics and linguistic ethnography. It uses illustrations from a recent academic literacies research project to reflect on methodology and to emphasise the importance of a prolonged engagement with participants' writing practices and experiences as well as the collection and analysis of a range of types of data to allow the researcher to become more familiar with the context. Methods such as allowing students to interpret their own writing, classroom observation and students' written literacy histories gave the researcher real insights into the way students made connections to their own familiar contexts in order to learn. The research also highlighted the manner in which communication between students and teaching staff can break down because teachers misinterpret student utterances when they do not understand or know the contexts that the students are drawing on. At the same time, however, the researcher sounds some caution about the use of dialogue in ethnographic methodologies because communication is a two-way process and allocation of linguistic resources has been unequal. Therefore, where students' resources do not match the context, they may struggle to communicate with the interviewer and to interpret their written texts. In these cases, interviewees who are first language speakers from privileged schooling backgrounds may be able to contextualise and interpret their writing more fully than interviewees who are speakers of English as a second or foreign language and who come from poorer rural schools.
\end{abstract}

Keywords: academic literacies research; contextualisation; ethnography; methodology; voice

\section{Introduction}

Haggis (2009) has encouraged higher education researchers to know 'not only more, but differently and to keep on extending the range of our different ways of knowing' (p. 383). She indicates that existing research in sociolinguistics might be one productive way of doing this. Theorists have long recognised that research in higher education, can benefit from structured disciplined attention to language because an investigation into language is crucial if we are to understand power relations, particularly privilege and inequality in societies (Blommaert, 2005; Bourdieu, 1991). Academic literacies 
research has proved to be very useful in uncovering societal inequalities perhaps because of its explicitly transformative approach (Lillis \& Scott, 2007).

Lillis and Scott (2007) have argued that the phrase 'academic literacies' is often used to simply refer to reading and writing in academic contexts, but academic literacies is now recognised internationally as a critical field of inquiry with a specific theoretical and ideological standpoint. In their 2007 article, Lillis and Scott have attempted to define this field, identifying literacy as social practice as the specific epistemology of academic literacies research and transformation as the ideology.

In academic literacies research the emphasis has shifted from texts towards Practices drawing on a number of different traditions such as the New Literacy Studies, critical discourse studies and the sociology of knowledge. The notion of writing as social practice acknowledges the socioculturally embedded nature of literacy practices (Street, 1984) as well as the power discrepancies in any literacy related activity. Lillis and Scott (2007) describe the idea of literacy as social practice as follows:

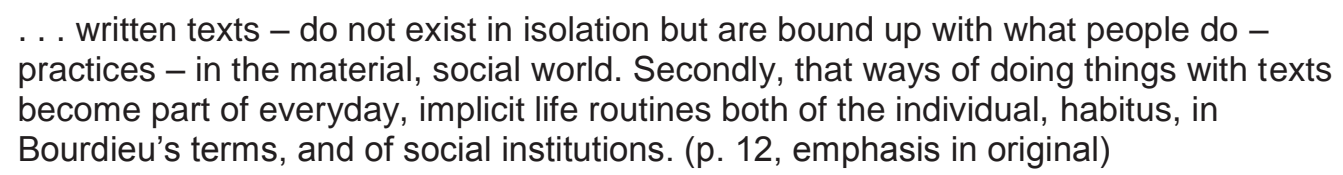

The ideological stance in academic literacies is an explicitly transformative one that is concerned with not only identifying academic conventions but locating them in relation to contested traditions of knowledge making. A transformative approach is interested in the ways in which such conventions impact on meaning making both for students and for professionals and in discovering alternative ways of meaning making by considering the resources that students bring as legitimate meaningmaking tools (Canagarajah, 2002; Clark \& Ivanic, 1997; Paxton, 2006, 2007).

As Ganobscik-Williams (2006) indicates the key contribution of an academic literacies approach is that it challenges the assumption of student deficit (that it is the students who are in deficit) and calls for academic institutions with all their takenfor-granted practices, values and roles to adapt to new higher education contexts where diversity and inclusion is emphasised.

Cadman (2003) sets an even greater challenge in relation to research writing. She critiques what she calls 'divine discourses' (p. 1) and 'epistemological racism' (p. 2) in the Western scholarly tradition and asks us to consider new ways of developing and expressing research knowledge in English so as to promote wider acceptance of hybrid academic discourses in international research communities, which would give recognition to the diversity of scholars. She says:

There seems to be a prevailing intellectual world view which does not recognise and therefore cannot know the limitations of its own taken-for-granted, almost sacred, understandings of what constitutes knowledge and its expression in the English language. (p. 1)

Cadman is concerned that as academics we are so steeped in the familiar Western scholarly traditions that we fail to 'hear' the voices of those from somewhat different contexts, a dilemma that is closely linked to the concern of this paper, which attempts to understand how researchers and teachers can get at voice in academic literacies research. The article will draw on data from a recent academic literacies research project to focus on methodology and to illustrate the ways in which ethnographic methodology, with its emphasis on the importance of a prolonged engagement with 
participants' writing practices and experiences as well as the collection and analysis of a range of types of data, allowed the researcher to become more familiar with the students' contexts and therefore may have given her more access to student voice. At the same time, however, the researcher points to some of the challenges related to the use of dialogue in ethnographic methodology because the communicative context in which such dialogue takes place may in itself prevent voicing because communication is a two-way process and allocation of linguistic resources has been unequal.

\section{Ethnography and its applicability for academic literacies research}

The primary methodology used in academic literacies research is ethnography, which is an empirical methodology concerned with collecting and analysing data from 'real world' contexts rather than from artificially created experimental situations. Ethnography is primarily about observation and informal conversations or interviews and involves prolonged engagement in a particular site and data is gathered from a variety of sources. The analysis of the data involves interpretations of the meanings and functions of human actions and the main aim of ethnography is for the researcher to make sense of events from the perspectives of the participants (Hammersley, 1994). Inevitably, language and communication can complicate this aim and it could be argued that getting access to the voice of participants through language is a key issue in any ethnographic approach. Gobo (2008, p. 12) argues that doing ethnographic research in societies to which the researcher belongs is particularly difficult because the researcher is not likely to 'see' the social structures on which that society rests, therefore he suggest that the researcher needs to abandon 'the natural attitude' that takes social conventions and everyday behaviour for granted as normal and learn to make the strange familiar and the familiar strange.

Because Street's (1984) ideological model of literacy acknowledges the socioculturally embedded nature of literacy practices and the power relations involved in all literacy-related activities, ethnography seems a very appropriate methodological tool for academic literacy research. Observation and informal dialogue over a prolonged period allow the researcher to get closer to understanding the practices surrounding the production of writers' texts and to elicit their perspectives on the meanings and functions of their texts. Gobo's word of caution is relevant for academic literacy researchers who may have difficulty recognising the limitations of their own taken-for-granted ideas of what knowledge is valued and how it should be expressed (Cadman, 2003, p. 1).

\section{Getting at voice in ethnographic research}

In research on writing there has been a long and respected tradition of focusing on the written text. Detailed analyses of texts and genres (for example, Hyland, 1999; Swales, $1990,2004)$ have led to far richer understandings of written text, and academic texts in particular, but in this tradition little consideration has been given to the contexts and the practices surrounding the production of these texts. As Lillis and Scott (2007) point out, one problem with the textual bias in writing research is that the pedagogy and research that follow from a focus on text in isolation may lead to purely textual solutions to what may be social and contextual issues. Academic literacies methodology, therefore, represents a significant shift in research on writing away from a focus on text to a focus on practice and the use of the tools of ethnography has been key. 
The relationship between the linguistic forms (the text) and the context is a crucial methodological and theoretical problem in the development of a critical study of language, and debates in a range of applied linguistic traditions, including academic literacies research and critical discourse analysis, have been drawn into discussions around this issue. There is a vast literature (for example, see Blommaert, 2005, 2007; Lillis, 2008; Rampton, 2007; Tusting \& Maybin, 2007) on this issue of context, which addresses the way in which linguistic forms become part of, get integrated in or become constitutive of larger activities in the social world. Academic literacies research, with its focus on understanding context and the practices surrounding the writing of the text, may allow for a narrowing of the text-context gap so that the researcher can get closer access to the writer's voice. But Blommaert $(2005,2007)$ notes that while ethnographic methods are valuable for enhancing context sensitive approaches to the study of academic writing, there are methodological tensions between the more restricted focus on linguistic text and the more open sensitivity to context.

Blommaert (2005) has taken this discussion further and argued that context is not something we can just add to text, context is text - we need to understand the contexts in which sense making practices develop because 'the way in which language fits into context is what creates meaning and what makes it (mis)understandable to others' (pp. 39-40). Misplacing utterances in contexts leads to breakdown in communication. Because the process of contextualisation is dialogical, it is not just the speaker who offers contexts to statements, but the other parties in the communication. Communication is a two-way process - it is produced by the speaker/writer but still has to be granted by someone else. Blommaert (2005) describes this as 'uptake' and he says a writer/ speaker can only have 'voice' if he has the capacity to cause an uptake of what he has communicated. He emphasises that communication is dependent on the resources that people have for communicating and he refers to resources as 'invisible' or 'forgotten' contexts. In order to have 'voice', people have to use the resources at their disposal and use them in clearly defined contexts. If the resources don't match the context, then people don't make sense. Therefore, he sees uptake as a very social process that is dependent on context and is embedded in power and inequality.

Blommaert is particularly concerned that under conditions of globalisation texts do not move easily from one context to another and he illustrates the way third world texts transported to first world contexts are often misinterpreted. He calls for first world theorists to scrutinize materials from the peripheries of the world system because this close scrutiny forces us to abandon notions of sharedness and to re-examine our own interpretive repertoires and practices.

Lillis (2008) attempts to address some of the tensions that Blommaert has highlighted by arguing for the importance of ethnography at three different levels in academic literacies research and she outlines these as ethnography as method, methodology and 'deep theorizing'. She acknowledges the limitations of 'talk around text' (ethnography as method) as a means to get at voice and suggests that we need to engage with ethnography as methodology, which involves engagement with participants over an extended period of time as well as the collection of data from multiple sources, so as to enable thick description (Geertz, 1973).

\section{Ethnographic study of student writing in economics}

Blommaert's (2005) concern that texts do not travel well between first and third world contexts is applicable in South Africa, a country that has often been described as having 
characteristics of both third and first world economies. It is particularly interesting in terms of my own research in a tertiary education setting in South Africa. Increased mobility, widening access to tertiary education and the need for social justice and national redress in post-apartheid South Africa has meant that students from very different contexts (remote rural villages) are entering the old historically white universities, yet the profile of academic staff at these institutions has not changed very much, which often means that the voices of these students do not travel.

Blommaert's (2005) notion of 'uptake' will be illustrated by a relook at some of my own research in the field of academic literacies. This was an ethnographic study of eight student writers from diverse backgrounds over a period of three years while they were in the process of acquiring the new academic discourse of economics (Paxton, 2003, $2006,2007)$. The study used an academic literacies approach, that is, sustained involvement in the contexts of production and multiple data sources as a methodology forunderstanding social practices. Data sources included students' written assignments, classroom observation, students' life histories and dialogue or 'talk around texts' with both the students and the lecturers. The 'talk around the texts' took place after a detailed linguistic and intertextual 1 analysis of the written assignments had been conducted and it gave the students an opportunity to interpret their own writing. This enabled me, as the researcher, to explore the complex situated meanings and social practices that are constituted in and by academic writing.

In this project, completed in 2004, I drew on Bakhtin's model of writer's voice, which is rather different from Blommaert's notion of voice as uptake and yet I believe the two theories complement one another. Bakhtin (1981) sees all texts as 'hybridised' and 'multivoiced' in which the different voices inter-animate and define one another (pp. 303-306). He recognises that all instances of language use have traces of other discourses and social languages. All texts are created out of borrowed language, but writers play a unique role in shaping their own words and texts:

The word in language is half someone else's. It becomes 'one's own only when the speaker populates it with his own intention, his own accent, when he appropriates the word, adapting it to his own semantic and expressive intention. (pp. 293-294)

From considering Bakhtinian notions of voice, I understand that in constructing a new text such as an economics essay, students may blend both economics texts and familiar texts associated with previous home and school contexts. Their texts are therefore addressed to, and anticipate, new audiences of economics educators while responding to previous ones.

For Bakhtin, humans are neither entirely autonomous and self-directed beings nor are they wholly shaped by social and institutional forces, rather they are agents who reproduce or transform the sociocultural resources. Voices are then a set of discourses that the writer brings to the act of writing and they are part of his/her social and historical formation. In the Bakhtinian sense a writer's voice can be considered as a repertoire or a unique combination of these discoursal resources. As the writer takes on the new discourses he/she takes ownership of these voices by assimilating, reworking and reaccentuating them (Bakhtin, 1986, p. 89).

In this article I use these two notions of voice as lenses to reconsider some of the data I collected and analysed in the research project described above. To avoid confusion, I will use the term 'voice' for what Bakhtin regards as a unique combination of discoursal resources and the word 'uptake' to refer to Blommaert's notion of voice. 


\section{Ethnographic methodology in action}

A reconsideration of the data, particularly the interviews with economics staff and the analysis of tutor feedback on the student essays, shows that there was a problem with staff 'uptake' of these students' texts. In Blommaert's (2005) words, meaning was 'produced' by the writer but was not 'granted' by their teachers because the texts were Not contextualised in the ways that the students desired. In most cases the reason for This breakdown in communication was a problem of resources: students did not have proficiency in English because they came from rural communities where English was an additional or foreign language, they were more comfortable with the spoken language than the written and they were unfamiliar with this new academic style of writing.

In the original study the use of intertextual analysis and 'talk around text', allowed me to probe writers' developing meanings and to understand more about acquisition processes and knowledge making practices. My findings showed that in the students' first university assignments they were building on a number of prior discourses from their home and school contexts in order to construct new knowledge in what was for them, the alien environment of the university. Thus, academic literacies methodology assisted me in getting closer to the contexts in which the texts were produced.

However, there were many indications of 'contextual mismatches' between students and teaching staff. For example, tutors and lecturers were puzzled by the frequent and 'inappropriate' use of question-and-answer-sequences in the writing of two students from rural villages, but the study was able to explain that these students had learned this older literary form, when studying Xhosa and Zulu praise poetryz at school. Their school teachers had encouraged them to transfer this discourse style, known in Xhosa as imbuzo buciko, to their own writing and they had tried it out in their first economics essay. One student used the question-and-answer style in the following way, to develop a discussion in her text:

What about these poor consumers who don't have any money, are their needs satisfied?

They are poor and they need goods that will cost less and maybe those goods won't be produced because many rich people do not want them. Is this market system pure

[fair]? Now the government should look at this and make a plan for those people.

Lecturers were not able to contextualise this use of question-and-answer sequences in the way the students wanted and the students did not have the resources to use the form proficiently, so there was a problem of 'uptake'.

However, in their later essays the students demonstrated that they had learned to adapt the rhetorical question more appropriately. In fact, one of the students was complimented on his use of questions and answers in the final economics essay. This showed that they had imported the older literary form and rearticulated and contextualised it in academic writing, providing evidence that students were using their more familiar discourses as a link to the new discourse and to facilitate acquisition.

The methodology also provided insights into the situated meanings 3 of the words and phrases students used, which helped in understanding the ways in which students were constructing meaning. Observation and 'talk about text' interviews with students were valuable in giving me access to the students' developing models and schema. An example from the study will illustrate. The student, Nomsa, referred to consumers as 'the boss of the market' instead of using the appropriate term 'consumer sovereignty', which in the economics of the market system means that consumers have sovereignty because they have the power to determine the types and quantities of goods and services 
that will be produced. The tutor commented in feedback on the essay that this was 'not academic language' but from my observation in tutorials and lectures, I was able to trace back to a tutorial where a tutor had simplified the concept of consumer sovereignty by explaining that a 'sovereign' was a 'king'. In her phrase, Nomsa has revealed her 'on the spot' image of the consumer as 'boss', a metaphor which she has assembled to help her understand the concept. Drawing on situated meanings and mental models is an important step in the learning process because this can provide students with a framework for learning new concepts. When a student uses a word or phrase that appears inappropriate to an academic or an economist, it may be that she has drawn on an association that gives her access to a new concept. Therefore, these traces of home and school discourses embedded in students' writing play an important role in assisting them to bridge the gaps, to conceptualise and to construct new discourses.

The research foregrounded the centrality of identity and identification in academic writing and highlighted the gaps and mismatches between the lecturers' expectations and what the students brought with them. One of the lecturers commented that, 'In the discipline of economics students' own experiences and personal meanings are not valued'. She felt that students were not understanding 'the need for economic analysis and economic method', instead they were using 'a very personal approach ... . relying on own knowledge, interpretations and opinions ... . what is important to the student is often not the focus of economic analysis.'

For instance, students sometimes used evidence from their own familiar contexts to support claims made in the economics essay. In the final first year essay, an analysis of South African Breweries as a monopoly power, Sibongile digressed to recite lines from one of her favourite television advertisements in order to illustrate the way the brewery uses advertisements to keep competitors out of the market and maintain its monopoly power:

\begin{abstract}
$\mathrm{SAB}$ is keeping the competitors out of the market by doing effective advertising, they make sure that they target everyone from soccer lover to rugby lover. Like if there are no beers then the soccer match will not start and that beer can bring people closer, even strangers and that if you want to welcome a stranger in your house you should give it a beer. There is one advert that seem to be working very well to beer drinkers which say 'one nation one soul, one beer one goo. . .' [goal] . . . soccer lovers love that one...
\end{abstract}

The economics lecturer commented that the student showed 'immaturity' in not 'understanding the economic approach'. However, Sibongile's vivid description of the television advertisements does demonstrate that she has understood the economic approach of supporting claims with evidence; the South African Breweries sporting advertisements (which are italicised in the excerpt above) provide evidence of the way the brewery holds onto its monopoly power. It seems that again there is a problem of uptake and that Sibongile's English and academic language resources are limited. When she recited the adverts and ditties, she drew on different, possibly 'immature' discourses, but they were ones that she could identify with and they assisted her in the theorising process. Given time and good feedback, she would probably learn to use her illustrations more proficiently.

Academic writing is ideologically inscribed in terms of the different meanings and identities it privileges. The students found that the academic practices, values and beliefs in the commerce faculty contrasted quite strongly with their own values and beliefs and they had difficulty accepting them and taking them on. It was evident that 
students were facing conflicts between familiar discourses and the dominant discourses of the academy. As they took on the dominant discourses of commerce, the beliefs and values central to the other discourses with which they were familiar became marginalised because there was strong pressure for them to conform to the dominant values. They believed that a tertiary education and, particularly, a degree in commerce was a way to fulfil their aspirations and escape from poverty. Therefore, in the latter part of the first year and into second year students became more skilled at hiding their own interests and experiences when they wrote the more formal essays. It was only occasionally in informal discussions that their values and experiences were disclosed and one gained insights into the kinds of conflicts they were facing. For instance, in online discussion forums on the gold mining industry in South Africa, lecturers were concerned that students again revealed their personal interests by calling for wage increases to follow increased gold prices instead of pointing to more likely economic consequences such as an increase in foreign exchange:

\footnotetext{
We see that the gold has increased but what about the wages of these people working hard under risky places?

The gold price has increased, putting Harmony [mining conglomerate] in a good financial position. The already starving families today have hope that Harmony is going to bring life back to the families.
}

Some of the students had family members working on the mines and these concerns revealed their social and historical formations reminding us of the conflict of identities they experienced as they grappled with shifts in their own lives in order to prepare themselves for careers as professionals in the world of business. They remind us too that acquisition of academic discourse is not a straightforward, single track process.

I have described the student writing in this study as 'interim literacies' (Paxton, 2007), which built on their past and present discourses, discourse strategies and genres in order to learn new ways of speaking and writing. The concept of interim literacies seems useful in a context of increasing cultural and linguistic diversity where students draw on a range of other discourses as they learn to make meaning in a new discourse. It also seemed appropriate in a context of changing socio-political and policy contexts globally but particularly in South Africa. It has allowed me to understand language and meaning making as a dynamic resource, constantly being adapted and transformed by its users. Clearer insights into interim literacies prompted me to question the dominant role of Western essayist literacy and traditional educational methodologies in our academic institutions. While the data does point to problems of 'uptake' in student writing, in an educational context the notion of interim literacies allows us to see this situation as fluid and changing.

\section{Methodological concerns}

Consideration of this research in the light of Blommaert's (2005) theorisation of resources as 'invisible' contexts raises concerns that methodologies such as the student writers' 'talk around text' and their literacy histories are somewhat problematic because of the differentials in the subjects' linguistic resources. While the interviews improved my ability to contextualise their texts, the subjects had to use English to communicate with me in the 'talk around text' situation because of my own linguistic limitations. Five of the subjects were not first-language English speakers, in fact students 
from rural South Africa have often been described as speakers of English as a foreign language, and this made it difficult for them to voice their meanings. Furthermore, in some cases they did not have the resources to interpret their writing as fully as the first language speakers from more privileged schools were able to do. With the ESL/EFL subjects, I had to work harder, asking more questions, probing further and relying on 'traces' such as intertextuality to find links to the social practices they were drawing on. In addition, the students' literacy histories were shaped by the linguistic resources they had for telling them. This meant that the middle-class English speakers in the case study were able to write stories that contextualised their literacy experiences more richly than the stories written by students from rural communities.

In a subsequent ethnographic study I have continued in this endeavour to understand the learning/acquisition processes of ESL students but I moved away from an analysis of students writing in English to analysing students working in multilingual Xhosa-English peer learning groups. These groups were led by a more senior Xhosa speaking tutor and the students used code switching to clarify meaning. This multilingual project has become a collaborative one in which a Xhosa speaking colleague and I have interviewed the students after the peer learning discussions and given them the option of being interviewed in Xhosa. Both the peer learning groups and the multilingual interviews have transformed the dynamics of the interaction and allowed voicing to emerge in ways that were different from a predominantly monolingual context. In the peer learning groups students code switched to articulate their understandings More clearly and more comfortably in their home language. This has created more Linguistic equality and reduced the text-context divide because both the tutor and my Xhosa speaking colleague have a closer understanding of the students' contexts. However, it has not resolved the issues of voicing because introducing a diversity of language(s) does not remove the power difference or the diversity issues. There have been added complexities in this research, because, as I am not fluent in Xhosa, I have had to rely on Xhosa translations of the peer learning discussions and of some of the interviews. These translations have been challenging because the same text has emerged with different interpretations according to who the translator may have been. One possible reason for this is that Xhosa in South Africa's urban centres is changing and becoming a more hybrid language and, therefore, translation has become a more challenging task.

\section{Conclusion}

This reflection on my earlier data collection methods has endorsed Blommaert's concern that we need to be cautious about using dialogue in our analysis because resources are aspects of social structure and resource allocation is never equal. The 'talk around text' method may as I have found, allow richer contextualisation for some research subjects than for others. However, this serves to emphasise the importance of what Lillis (2008, p. 355) calls 'ethnography as methodology' an approach that is not confined to 'talk around text' but incorporates a much broader methodological strategy of sustained engagement in participants' writing or learning worlds and the collection and analysis of a range of types of data to allow the researcher to become more familiar with the context. This more comprehensive approach with its recognition of the value of thick participation gave me real insights into the way students learned and the way communication with their teachers broke down because the teachers were not contextualising the student writing in the way that the students would have liked. 
I have argued that these texts written by working class and rural students who are second language speakers of English may not have caused uptake amongst their lecturers because lecturers did not understand the contexts in which the sense making practices developed and because students may not have had the linguistic resources to communicate their meanings appropriately. However, my research illustrates that the situation is a little more complex than this. Voice is not fixed or static, it is dynamic and students are agents in their own learning processes. They are using these interim literacies - their familiar practices, metaphors and illustrations - quite consciously to assist them in learning and acquiring the new discourse of economics and, while initially their voices may fail to communicate, they do learn over a period of time and with appropriate assistance to make their meanings clearer. In a Bakhtinian sense, the writer develops his/her own unique voice by assimilating and reworking past and present discourses, therefore I would argue that Blommaert's notion of uptake could be seen as being rather limited if it overlooks this sense of student agency and the dynamic nature of voice.

\section{Acknowledgements}

I gratefully acknowledge grants from the Spencer Foundation and the Faculty Research Committee at the University of Cape Town, which made this research possible.

\section{Notes}

1. The term 'intertextual' is used very broadly to refer to all ways in which a specific text relates to other texts and voices.

2. The question-and-answer style can be found in Zulu poetry, for instance in the three parallel couplets below, which have been taken from the translation of Zwide's praise poem (Cope, 1968, p. 128):

Amongst the roads which one does he resemble? $\mathrm{He}$ is like the one which cuts straight across;

Amongst the trees which one does he resemble?

$\mathrm{He}$ is like the hardy essenwood tree;

Amongst the snakes which one does he resemble?

$\mathrm{He}$ is like the large green one which represents the ancestors.

3. Words for individual speakers have 'situated meanings' related to the specific contexts and to the images and patterns that speakers associate with them from their past experiences (Gee, 1999).

\section{References}

Bakhtin, M.M. (1981). Discourse in the novel. In M. Holquist (Ed.), The dialogic imagination: Four essays by M. Bakhtin (C. Emerson \& M. Holquist, Trans., pp. 259 -422). Austin: University of Texas Press.

Bakhtin, M.M. (1986). The problem of speech genres. In C. Emerson \& M. Holquist (Eds.), Speech genres and other late essays (V. W. McGee, Trans., pp. 60 - 102). Austin: University of Texas Press.

Blommaert, J. (2005). Discourse: A critical introduction. Cambridge: Cambridge University Press.

Blommaert, J. (2007). On scope and depth in linguistic ethnography. Journal of Sociolinguistics, 11(5), $682-688$.

Bourdieu, P. (1991). Language and symbolic power (G. Raymond \& M. Adamson, Trans.) Cambridge, MA: Polity Press. 
Cadman, K. (2003). Divine discourse: Plagiarism, hybridity and epistemological racism. Paper presented at LED 2003, 1st International Conference on Language, Education \& Diversity. Retrieved May 10, 2010, from http://hdl.handle.net/2440/39833

Canagarajah, S. (2002). Critical academic writing and multilingual students. Ann Arbor: University of Michigan Press.

Clark, R., \& Ivanic, R. (1997). The politics of writing. London: Routledge.

Cope, A.T. (1968). Izibongo Zulu praise poems. London: Oxford University Press.

Ganobcsik-Williams, L. (2006). Starting points for theory and pedagogy: Introduction. In L. Ganobcsik-Williams (Ed.), Teaching academic writing in UK higher education: Theories, practices and models (pp. $1-3$ ). Basingstoke, UK: Palgrave.

Gee, J. (1999). An Introduction to discourse analysis: Theory and method. London and New York: Routledge.

Geertz, C. (1973). The interpretation of cultures. New York: Basic Books.

Gobo, G. (2008). Doing ethnography (A. Belton, Trans.). London: Sage.

Haggis, T. (2009). What have we been thinking of? A critical overview of 40 years of student learning research in higher education. Studies in Higher Education, 34(4), 377 -390.

Hammersley, M. (1994). Introducing ethnography. In D. Graddol, J. Maybin, \& B. Stierer (Eds.), Researching language and literacy in social context (pp. 1-17). Clevedon, $\mathrm{OH}$ \& Milton Keynes, UK: Multilingual Matters/OUP.

Hyland, K. (1999). Disciplinary discourses: Writer stance in research articles. In C. Candlin and K. Hyland (Eds.), Writing, texts, processes and practices (pp. $99-121)$. London and New York: Longman.

Lillis, T., \& Scott, M. (2007). Defining academic literacies research: Issues of epistemology, ideology and strategy. Journal of Applied Linguistics, 4(1), 5- 32.

Lillis, T. (2008). Ethnography as method, methodology and 'deep theorizing': Closing the gap between text and context in academic writing research. Written Communication, 25(3), 353- 387.

Paxton, M. (2003). Developing academic literacies in Economics in a South African Univesity. Literacy and Numeracy Studies, 13(1), $1-14$.

Paxton, M. (2006). Intertextual analysis: A research tool for uncovering the writer's emerging meaning. In L. Thesen \& E. van Pletzen (Eds.), Academic literacies and the languages of change (pp. 84-103). London: Continuum.

Paxton, M. (2007). Students' interim literacies as a dynamic resource for teaching and transformation. Southern African Linguistics and Applied Language Studies, 25(1), 45- 55.

Rampton, B. (2007). Neo-Hymesian linguistic ethnography in the United Kingdom. Journal of Sociolinguistics, 11(5), 584- 607.

Street, B. (1984). Literacy in theory and practice. London: Cambridge University Press.

Swales, J.M. (1990). Genre analysis. Cambridge: Cambridge University Press.

Swales, J.M. (2004). Research genres: Explorations and applications. Cambridge: Cambridge University Press.

Tusting, K., \& Maybin, J. (2007). Linguistic ethnography and interdisciplinarity: Opening the discussion. Journal of Sociolinguistics, 11(5), 575 -583. 